\title{
Peertechz
}

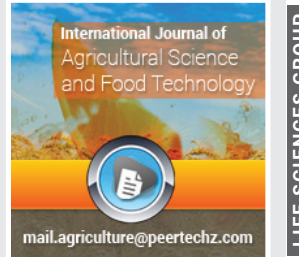

Research Article

\section{Evaluation of the Existing Food Safety Management System (FSMS) Implemented in Sudanese Sugar industries}

\section{AM Babeker ${ }^{1}$, MA Ebrahiem ${ }^{2 *}$, AR Ahmed ${ }^{3}$ and GA Mustafa $^{1}$}

'Department of Food Science and Technology, Faculty of Natural Resources and Environmental Studies, University of Kordofan, Elobeid, Sudan

${ }^{2}$ Department of Animal Production, Faculty of Natural Resources and Environmental Studies, University of Kordofan, Sudan

${ }^{3}$ Ahfad University for Women, Omdurman, Sudan
Received: 13 December, 2021

Accepted: 11 January, 2022

Published: 12 January, 2022

*Corresponding author: MA Ebrahiem, Department of Animal Production, Faculty of Natural Resources and Environmental Studies, University of Kordofan, Sudan, Email:mahaali5656@gmail.com

ORCID: https://orcid.org/0000-0003-3545-1242

Keywords: Evaluation; FSMS; Sudanese sugar industries; ISO 22000

Copyright License: (c) 2022 AM Babeker, et al. This is an open-access article distributed under the terms of the Creative Commons Attribution License, which permits unrestricted use, distribution, and reproduction in any medium, provided the original author and source are credited.

https://www.peertechzpublications.com

Check for updates

\section{Abstract}

The present study was conducted in all Sudanese Sugar industries; namely; (Kenana, White Nile, Assalaya, Sennar, Guneid and New Halfa) during production season at 2017. The study aimed to evaluate the existence of food safety Management System implemented by all Sudanese sugar industries with reference to the Food Safety Management System (FSMS) of the International Standard Organization (ISO 22000). The data were collected using ISO 22000 checklist and direct interviews. Likert FivePoint Scale was used in scoring the checklist statement and the arithmetic mean was obtained. The results of the study revealed that the general requirement of the Food Safety Management System was not applicable; score less than (1.8 points) whereas its documentation that supports food safety programs scored major deficiencies in five industries less than 3.4 points. Secondly, the requirement of management responsibility attained non-compliance in three industries. Thirdly, the Requirement of Resource Management in all Sudanese sugar industries had major deficiencies except one factory scored minor deficiency less than 4.2 points. Fourthly, Planning and realization of safe products requirement was non-compliance in three factories less than 2.6 points and not applicable in the rest factories. Finally, the requirement of validation, verification and improvement of food safety programs was not applicable in all Sudanese Sugar Industries where it recorded less than 1.8 points. Lack of top management commitment and involvement and lack of government support represent the main constraints and barriers to implementing food safety systems in Sudanese sugar companies. Sudanese sugar industries need to implement food safety systems like GMP (Good Manufacturing Practices) and HACCP (Hazard Analysis Critical Control Point System) that represent the minimum requirement to implement Food Safety Management System.

\section{Introduction}

Food safety represents a fundamental public health concern for every actor involved along the food supply chain. Now a day, the need for a consistent approach to food safety management along the whole food supply chain, from the farm to the table, is vital. The World Health Organization estimates that more than 600 million people fall ill and 420000 die every year from eating food contaminated with bacteria, viruses, parasites, toxins or chemicals. However, these numbers represent only 'the tip of the iceberg' as comprehensive surveillance data for food-borne illnesses is not available everywhere. When food is not safe, humans cannot benefit from its nutritional value and cannot grow and develop [1].
More organizations are deciding to develop a comprehensive food safety management system which is critical to the success of the business. The food safety management system helps the company protect its competitive marketplace, customers and the community, guaranteeing continuous prevention of foodborne illnesses, promotion of safe to eat foods, gain of more of customer confidence, and gain of market reputation. More organizations are now choosing to have their food safety management systems certified based on internationally recognized standards and practices [2]. Food safety systems should be designed to control the production process and be based on preventive principles and concepts [3].

As such, the international standard ISO $22000[4,5]$ Food 
Safety Management System (FSMS) - Requirements for any organization in the food chain was created to help organizations identify and control food safety hazards by developing and adopting a food safety management system $[4,5]$.

The FSMS is a vital part of any modern food business. Organizations in the food chain need to demonstrate their ability to control food safety hazards in order to ensure that food is safe at the time of human consumption. A well-established FSMS allows for identifying risks to food safety and detailing how they are monitored and controlled in the organization [6]. Therefore, the international standard ISO 22000 specifies basic requirements for FSMS and provides a systematic methodology for analyzing food processes, determining the possible hazards, and designating the critical control points and risks $[7,8]$. These steps are necessary to prevent unsafe food from reaching the consumer [6]. The development and application of FSMS is continuously increasing [9]. However, there is a lack of research in its use in the [10].

The FSMS represents a group of practices and procedures tented to prevent foodborne illness by actively controlling risks and hazards throughout the flow of food [11,12]. The International Standards Organization published the ISO 22000 in September 2005 which outlines the requirements for implementing FSMS in all types of organizations along the food chain $[5,6]$.

\section{Problem statement}

Food safety measures adopted by the sugar industries of Sudan have witnessed cross-contamination that led to substantial illness for consumers. These were reported to include inadequacy of well-planned facilities, lack of sanitary conditions management, lack of training, abuse of governmental regulations and laws (food codes), and economic losses due to declining European markets $[9,10]$.

\section{Justification of research theme}

The available work on quality assurance systems implemented by the Sudanese sugar industry would remain mere claims unless scientifically verified with reference to international standards. This study aimed to evaluate the existing food quality and safety system applied by the Sudanese $[4,5]$.

\section{Materials and methods}

\section{Sugar industries}

This study was conducted in all sugar industries of the Sudan, namely New Halfa, Guneid, Assalaya, Sennar, Kenana and White Nile Sugar industries. Industry codes were applied rather than actual expeller names of each sugar industry to protect the reputation of the expeller. Numerical scores were given to sanitary observation on 5 classes of complementary conditions: 5- full compliance, 4- minor deficiency, 3- major classifications were developed accordingly to the issued standards criteria. Sugar Industry in relation to ISO 22000 System requirements deficiency, 2- non-compliance and 1- not applicable. These

\section{Data collection}

The data collection was done through observation checklist and direct interviews with top management and senior managers in a production line. Six visits were carried out to Industries to Evaluation the existing situation of the Food Safety Management System $[2,4,5]$. And their prerequisites programmers in the Sudanese Sugar industries based on the standard issued by the International Standardization Organization $[4,5]$. And evaluation of each industry performance was documented.

\section{Assessment of Food Safety Management System (ISO 22000) in Sudanese sugar industry audit checklist}

This assessment was carried out by using the Audit Checklist as prepared by Total Quality Certification Services International TOCSI [13-15]. Scoring system was used to evaluate the implementation of Food Safety Management System as following in Tables 1-3 according to Likert FivePoint Scales [15].

Section (1) Assessment of Food Safety Management System (FSMS) in Sudanese sugar industries and their prerequisites program

These are general requirements of Food Safety Management System, Management Responsibility, Resource Management,

\begin{tabular}{|c|c|c|c|c|}
\hline \multicolumn{5}{|c|}{ Possible answer } \\
\hline Strongly Agree & Agree & $\begin{array}{c}\text { Neither agree or } \\
\text { disagree }\end{array}$ & Disagree & Strongly Disagree \\
\hline \multicolumn{5}{|c|}{ Possible Points for the question } \\
\hline Score $=5$ & Score $=4$ & Score $=3$ & Score $=2$ & Score $=1$ \\
\hline Points & Points & Points & Points & Points \\
\hline
\end{tabular}

Table 2: Compliance for questions in Food Safety Management System.

\begin{tabular}{|c|c|}
\hline Answer & Criteria used \\
\hline $\begin{array}{l}\text { Total } \\
\text { Compliance } \\
\text { Or Strongly } \\
\text { Agree }\end{array}$ & To meet the question and/or compliance criteria in full. \\
\hline $\begin{array}{l}\text { Minor } \\
\text { Deficiency } \\
\text { Or Agree }\end{array}$ & $\begin{array}{l}\text { To have minor deficiencies against the question and/or compliance } \\
\text { criteria. To have single or isolated non-severe deficiencies (usually } \\
\text { up to three) against the question and/or compliance criteria. To have } \\
\text { covered most of the question compliance criteria, but not all. }\end{array}$ \\
\hline $\begin{array}{l}\text { Major } \\
\text { Deficiency } \\
\quad \text { or } \\
\text { Veither agree } \\
\text { or disagree }\end{array}$ & $\begin{array}{l}\text { To have major deficiencies against the question and/or compliance } \\
\text { criteria. To have numerous non-severe deficiencies (usually more } \\
\text { than three) against the question and/or compliance criteria. To } \\
\text { have single or isolated severe deficiencies against the question } \\
\text { and/or compliance criteria. To have covered some of the question } \\
\text { compliance criteria, but not most of it. }\end{array}$ \\
\hline $\begin{array}{l}\text { Non- } \\
\text { compliance } \\
\text { or } \\
\text { Disagree }\end{array}$ & $\begin{array}{l}\text { To have not met the question and/or compliance criteria } \\
\text { requirements at all. Having systematic deficiencies against the } \\
\text { question and/or compliance criteria (severe or Non-severe issue). }\end{array}$ \\
\hline $\begin{array}{l}\text { Not } \\
\text { applicable } \\
\text { Or } \\
\text { Strongly } \\
\text { Disagree }\end{array}$ & $\begin{array}{l}\text { The requirement described in the question is not applicable for the } \\
\text { operation being Audited. Justification should be provided in the } \\
\text { auditor's comments. Be aware that there are some questions that do } \\
\text { not allow answering Non-applicable. }\end{array}$ \\
\hline
\end{tabular}

Citation: AM Babeker, MA Ebrahiem, AR Ahmed, GA Mustafa (2022) Evaluation of the Existing Food Safety Management System (FSMS) Implemented in Sudanese Sugar industries. J Agric Sc Food Technol 8(1): 021-027. DOI: https://dx.doi.org/10.17352/2455-815X.000140 
Planning and realization of safe products and Validation, verification and improvement of the food safety management system

Section (2) Identification the difficulties and challenges obstacles to implementing Food Safety Management Systems ISO 22000 in Sudanese sugar industries and their prerequisites program

Statistical analysis: The quantitative collected data was entered and analyzed by using Statistical Packing for Social Sciences (SPSS) version 16. To obtain descriptive statistics of percentages and arithmetic mean through using Likert FivePoint Scales [15].

\section{Results and discussions}

Evaluation of the existing situation of Food Safety Management System in Sudanese Sugar Industry with reference to FSMS of the ISO 22000, 2005

The general requirements: Table 4 shows that, the elements

Table 3: Audit scoring summary criteria in case of mean and percentage. How to explain meaning of arithmetic mean and percentage

\begin{tabular}{|c|c|c|c|}
\hline \multicolumn{2}{|c|}{$\begin{array}{l}\text { How to explain meaning of arithmetic } \\
\text { mean }\end{array}$} & \multicolumn{2}{|c|}{ How to explain meaning of percentage $\%$} \\
\hline Numerical & Views & Numerical & Views \\
\hline$M<1.8$ & $\begin{array}{c}\text { Not applicable } \\
\text { Or } \\
\text { Strongly Disagree }\end{array}$ & $P<36 \%$ & $\begin{array}{c}\text { Not applicable } \\
\text { Or } \\
\text { Strongly Disagree }\end{array}$ \\
\hline $1.8 \leq M<2.6$ & $\begin{array}{c}\text { Non-compliance } \\
\text { Or } \\
\text { Disagree }\end{array}$ & $36 \% \leq M<52 \%$ & $\begin{array}{c}\text { Non-compliance } \\
\text { Or } \\
\text { Disagree }\end{array}$ \\
\hline $2.6 \leq M<3.4$ & $\begin{array}{c}\text { Major } \\
\text { Deficiency } \\
\text { Or Neither agree or } \\
\text { disagree }\end{array}$ & $52 \% \leq M<68 \%$ & $\begin{array}{c}\text { Major } \\
\text { Deficiency } \\
\text { Or Neither agree or } \\
\text { disagree }\end{array}$ \\
\hline $3.4 \leq M<4.2$ & $\begin{array}{l}\text { Minor Deficiency } \\
\text { Or Agree }\end{array}$ & $68 \% \leq M<84 \%$ & $\begin{array}{l}\text { Minor Deficiency } \\
\text { Or Agree }\end{array}$ \\
\hline $4.2 \leq M \leq 5$ & $\begin{array}{l}\text { Total Compliance } \\
\text { Or Strongly Agree }\end{array}$ & $84 \% \leq M \leq 100 \%$ & $\begin{array}{l}\text { Total Compliance } \\
\text { Or Strongly Agree }\end{array}$ \\
\hline
\end{tabular}

Sorrel Brown, 2010 of General requirement were not implemented in all Sudanese sugar industries when compared with the FSMS requirements of the ISO $22000[4,5,16]$ and these results mean the factories were not established, documented and implemented any food safety system to ensure food safety, the food safety system not maintained and updated, the scope of the food safety system not defined and the food safety hazards that may be reasonably expected to occur in relation to products within the scope of the system not identified, evaluated and controlled in such manner that the products of the industries don't directly or indirectly, harm the consumer.

The documentation requirements: Table 4 shows that the documentation and record used in the Sudanese sugar industries obtained score not applicable in all industries compared with reference to FSMS requirements of the ISO $22000[4,5]$. The result indicates that documented and record statement were not complying with food safety policy and related objectives, not define the scope of the food safety management system, Scope to specify the products or product categories, processes and production sites addressed by the FSMS, not Identify, evaluate and control the food safety hazards, communication of appropriate information regarding safety issues related to products throughout food chain not carried out in addition to communication of information concerning development, implementation and updating of FSMS throughout the organization.

\section{Category of Management responsibility requirements used in Sudanese sugar industries with reference to FSMS of the ISO 22000, 2005}

Table 5 shows that the General Arithmetic means of Management responsibility was 1.88 and it was reported in factories Kenana, White Nile and New Halfa this means the corresponding is non-compliance according to FSMS of the ISO $22000[4,5]$. The non-compliance scored in the three factories resulted from Top management not providing evidence of its commitment to established, implemented and maintained effective arrangements for External communication and

Table 4: Food Safety Management System used in Sudanese Sugar Industries with reference to FSMS of the ISO 22000, 2005:

\begin{tabular}{|c|c|c|c|c|c|c|c|}
\hline \multirow{2}{*}{$\begin{array}{c}\text { Food Safety Management System used with } \\
\text { reference to FSMS }\end{array}$} & \multirow[b]{2}{*}{$\begin{array}{c}\text { Elements } \\
\text { Number }\end{array}$} & \multicolumn{6}{|c|}{ Factories } \\
\hline & & Kenana & White Nile & Assalaya & Sennar & Guneid & New Halfa \\
\hline General requirements of FSMS & 5 & 1 & 1 & 1 & 1 & 1 & 1 \\
\hline $\begin{array}{l}\text { Documented statements of a food safety } \\
\text { policy and related objectives }\end{array}$ & 3 & 3 & 4 & 3 & 3 & 3 & 3 \\
\hline $\begin{array}{l}\text { Documents needed by the organization } \\
\text { ensure the effective development, } \\
\text { implementation and updating of the food } \\
\text { safety program. }\end{array}$ & 7 & 3 & 4 & 4 & 4 & 3 & 3 \\
\hline $\begin{array}{l}\text { Documents ensure that all proposed changes } \\
\text { are reviewed prior to implementation to } \\
\text { determine their impact on the food safety } \\
\text { system. }\end{array}$ & 3 & 2 & 2 & 2 & 2 & 2 & 2 \\
\hline $\begin{array}{l}\text { Records remain legible, readily identifiable } \\
\text { and retrievable. }\end{array}$ & 4 & 4 & 4 & 4 & 4 & 3 & 3 \\
\hline General Arithmetic means & & 3.00 & 3.5 & 3.25 & 3.25 & 2.75 & 2.75 \\
\hline Verbal & & Major deficiency & $\begin{array}{c}\text { Minor } \\
\text { deficiency }\end{array}$ & Major deficiency & Major deficiency & Major deficiency & $\begin{array}{c}\text { Major } \\
\text { deficiency }\end{array}$ \\
\hline
\end{tabular}

Citation: AM Babeker, MA Ebrahiem, AR Ahmed, GA Mustafa (2022) Evaluation of the Existing Food Safety Management System (FSMS) Implemented in Sudanese Sugar industries. J Agric Sc Food Technol 8(1): 021-027. DOI: https://dx.doi.org/10.17352/2455-815X.000140 
Table 5: The requirement of Management responsibility used in Sudanese Sugar Industries with reference to FSMS of the ISO 22000, 2005.

\begin{tabular}{|c|c|c|c|c|c|c|c|}
\hline & & \multicolumn{6}{|c|}{ Factories } \\
\hline Management responsibility & $\begin{array}{l}\text { Elements } \\
\text { Number }\end{array}$ & Kenana & White Nile & Assalaya & Sennar & Guneid & New Halfa \\
\hline Management commitment & 6 & 4 & 4 & 3 & 3 & 3 & 4 \\
\hline $\begin{array}{l}\text { Has top management defined, documented and } \\
\text { communicated its food safety policy? }\end{array}$ & 7 & 1 & 1 & 1 & 1 & 1 & 1 \\
\hline $\begin{array}{l}\text { Does top management ensure that: the } \\
\text { planning is carried out to meet the requirements } \\
\text { of ISO } 22000\end{array}$ & 2 & 1 & 1 & 1 & 1 & 1 & 1 \\
\hline $\begin{array}{l}\text { Is the responsibility and authorities assigned } \\
\text { to all personnel to report the problems with the } \\
\text { food safety management to identified person? }\end{array}$ & 3 & 3 & 3 & 3 & 3 & 3 & 3 \\
\hline $\begin{array}{l}\text { Has top management appointed a food safety } \\
\text { team leader who }\end{array}$ & 4 & 1 & 1 & 1 & 1 & 1 & 1 \\
\hline $\begin{array}{l}\text { Has the Factory established, implemented and } \\
\text { maintained effective arrangements for External } \\
\text { communication }\end{array}$ & 5 & 2 & 2 & 2 & 2 & 2 & 2 \\
\hline $\begin{array}{l}\text { Has the Factory established, implemented and } \\
\text { maintained effective arrangements for Internal } \\
\text { communication }\end{array}$ & 3 & 1 & 1 & 1 & 1 & 1 & 1 \\
\hline $\begin{array}{l}\text { Has top management established, implemented } \\
\text { and maintained procedures to manage potential } \\
\text { emergency situations and accidents that can } \\
\text { impact food safety and which are relevant to } \\
\text { the role of the } \\
\text { Factory in the food chain? }\end{array}$ & 1 & 1 & 1 & 1 & 1 & 1 & 1 \\
\hline $\begin{array}{l}\text { Does top management review the Factory's } \\
\text { food safety management system, at planned } \\
\text { intervals, to ensure its continuing suitability and } \\
\text { effectiveness? }\end{array}$ & 14 & 2 & 2 & 2 & 2 & 2 & 2 \\
\hline General Arithmetic means & 8 & 1.88 & 1.88 & 1.75 & 1.75 & 1.75 & 1.88 \\
\hline Verbal & Elements & Non-compliance & Non-compliance & Not applicable & Not applicable & Not applicable & Non-compliance \\
\hline
\end{tabular}

Conducting management reviews the Factory's food safety system, at planned intervals, to ensure its continuing suitability and effectiveness. While the factories Assalaya, Sennar and Guneid had the arithmetic mean of 1.75 , thus the Management responsibility was not applicable. This means the Factories were not established, implemented and maintained effective arrangements for internal communication, not have food safety policy, not have planning to meet the requirements of ISO 22000 and not have procedures to manage potential emergency situations and accidents that can impact food safety and which are relevant to the role of the Factory in the food chain.

\section{Category of resource management requirements used in Sudanese sugar Industries with reference to FSMS of the ISO 22000, 2005}

Table 6 shows that the General Arithmetic means of Resource Management was 3.50 reported in factory 2 this mean is corresponding the minor deficiency according to FSMS of the ISO $22000[2,3]$. While the factories Kenana, Assalaya, Sennar, Guneid, and New Halfa had the arithmetic means of 3, $3,3,2.75$ and 2.75 respectively as a result, the corresponding major deficiencies in requirement of resource management for the establishment, management and maintenance of the work environment needed to implement the requirements of the ISO $22000[4,5]$.
Category of the planning and realization of safe products requirement used in Sudanese sugar Industries with reference to FSMS of the ISO 22000, 2005

Table 7 Shows that the General Arithmetic means of Planning and realization of safe products were 2.23, 2.23 and 2.00 reported in factories Kenana, White Nile and New Halfa this means the corresponding is non-compliance according to FSMS requirements of the ISO $22000[4,5]$. While the factories Assalaya, Sennar and Guneid had the arithmetic means 1.54, 1.38 and 1.38 respectively, as a result, the corresponding not applicable according to FSMS requirements of the ISO 22000 $[4,5]$.

The non-compliance scored in the three factories number Kenana, White Nile and New Halfa resulted from lack of control of nonconformity (corrections and corrections actins) and Factories not handling of potentially unsafe products in proper manner (general, Evaluation for release, Disposition). While the not applicable scored in the three factories number Assalaya, Sennar and Guneid resulted from the fact that all factories investigated were not established Preliminary steps to enable hazard analysis, not carried out the verification planning, were not established traceability system to identification of product lots and their relation to batches of raw materials, processing and delivery records and not have withdrawals system to prevent or eliminated unsafe products from reaching to costumers. 
Table 6: Requirement of Resource management used in Sudanese Sugar Industries with reference to FSMS of the ISO 22000, 2005.

\begin{tabular}{|c|c|c|c|c|c|c|c|}
\hline \multirow[b]{2}{*}{ Resource management } & \multirow[b]{2}{*}{$\begin{array}{c}\text { Elements } \\
\text { Number }\end{array}$} & \multicolumn{6}{|c|}{ Factories } \\
\hline & & Kenana & White Nile & Assalaya & Sennar & Guneid & New Halfa \\
\hline $\begin{array}{l}\text { Does the Factory provide adequate resources for } \\
\text { establishment, implementation, maintenance and } \\
\text { updating of the food safety management? }\end{array}$ & 3 & 3 & 3 & 3 & 3 & 3 & 3 \\
\hline Human resources, Competence, awareness & 4 & 3 & 3 & 3 & 3 & 3 & 3 \\
\hline $\begin{array}{l}\text { Does the Factory provide the resources for the } \\
\text { establishment the infrastructure needed to } \\
\text { implement ISO } 22000 \text { standard? }\end{array}$ & 1 & 3 & 4 & 3 & 3 & 3 & 3 \\
\hline $\begin{array}{l}\text { Does the Factory provide the resources for the } \\
\text { establishment, management and maintenance of } \\
\text { the work environment needed to implement the } \\
\text { requirements of } 22000\end{array}$ & 1 & 3 & 4 & 3 & 3 & 2 & 2 \\
\hline General Arithmetic means & 4 & 3 & 3.5 & 3 & 3 & 2.75 & 2.75 \\
\hline
\end{tabular}

Verbal

Elements Major deficiency Minor deficiency Major deficiency Major deficiency Major deficiency Major deficiency

Table 7: Requirement of the Planning and realization of safe products in Sudanese Sugar Industries with reference to FSMS of the ISO $22000,2005$.

\begin{tabular}{|c|c|c|c|c|c|c|c|}
\hline & & \multicolumn{6}{|c|}{ Factories } \\
\hline Planning and realization of safe products & $\begin{array}{l}\text { Elements } \\
\text { Number }\end{array}$ & Kenana & White Nile & Assalaya & Sennar & Guneid & New Halfa \\
\hline $\begin{array}{l}\text { General requirements of Planning and } \\
\text { realization of safe products }\end{array}$ & 2 & 4 & 4 & 3 & 2 & 2 & 2 \\
\hline $\begin{array}{l}\text { Has the Factory established, implemented and } \\
\text { maintained PRP(s) to assist in controlling all } \\
\text { hazards }\end{array}$ & 4 & 3 & 3 & 3 & 2 & 2 & 2 \\
\hline Preliminary steps to enable hazard analysis & 5 & 1 & 1 & 1 & 1 & 1 & 1 \\
\hline $\begin{array}{l}\text { Does the food safety team conduct a hazard } \\
\text { analysis to determine which hazards need to } \\
\text { be controlled, the degree of control required to } \\
\text { ensure food safety? }\end{array}$ & 4 & 3 & 3 & 1 & 1 & 3 & 1 \\
\hline $\begin{array}{l}\text { Establishing the operation prerequisite } \\
\text { programmes (PRPS) }\end{array}$ & 5 & 3 & 3 & 1 & 1 & 3 & 1 \\
\hline Establishing the HACCP plan & 6 & 3 & 3 & 1 & 1 & 3 & 1 \\
\hline $\begin{array}{c}\text { Factory update the following information } \\
\text { in operational PRPs and HACCP plan, if } \\
\text { necessary: }\end{array}$ & 4 & 3 & 3 & 1 & 1 & 3 & 1 \\
\hline the Verification planning carried out & 5 & 1 & 1 & 1 & 1 & 1 & 1 \\
\hline $\begin{array}{l}\text { Has the Factory established traceability } \\
\text { system to identification of product lots and } \\
\text { their relation to batches of raw materials, } \\
\text { processing and delivery records? }\end{array}$ & 3 & 1 & 1 & 1 & 1 & 1 & 1 \\
\hline $\begin{array}{l}\text { Control of nonconformity } \\
\text { (Corrections) }\end{array}$ & 4 & 2 & 2 & 2 & 2 & 2 & 2 \\
\hline $\begin{array}{l}\text { Control of nonconformity } \\
\text { (Corrections actins) }\end{array}$ & 3 & 2 & 2 & 2 & 2 & 2 & 2 \\
\hline $\begin{array}{l}\text { Control of nonconformity } \\
\text { ( Withdrawals) }\end{array}$ & 4 & 1 & 1 & 1 & 1 & 1 & 1 \\
\hline $\begin{array}{l}\text { Does the Factory Handling of potentially } \\
\text { unsafe products (general, Evaluation for } \\
\text { release, Disposition). }\end{array}$ & 8 & 2 & 2 & 2 & 2 & 2 & 2 \\
\hline General Arithmetic means & 10 & 2.23 & 2.23 & 1.54 & 1.38 & 1.38 & 2.0 \\
\hline Verbal & Elements & Non-compliance & Non-compliance & Not applicable & Not applicable & Not applicable & Non-compliance \\
\hline
\end{tabular}

\section{Category validation and verification of safety programs requirement used in Sudanese sugar Industries with re- ference to FSMS of the ISO 22000, 2005}

The results show that the General Arithmetic means of the Validation and verification of food safety programs in all Sudanese sugar industries was score 1point for Validation and verification respectively, this mean the corresponding not applicable according to FSMS requirements of the ISO $22000[4,5]$. Not applicable scored in the six factories for the reason that all factories did not have a plan and implement the 
processes needed to validate control measures combinations to verify and improve the food safety program. Concerning to the verification food safety program not applicable scored resulted by all Factories were not conduct internal audits at planned intervals to determine whether the food safety program.

\section{Category improvement and updating food safety pro- gram requirement used in Sudanese Sugar Industries with reference to FSMS of the ISO 22000, 2005}

The results shows that the General Arithmetic means of the improvement and Updating of food safety programs in all Sudanese sugar industries was 1for improvement and Updating respectively, this mean is corresponding the not applicable according to FSMS requirements of the ISO $22000[4,5,16]$. Not applicable scored in the six factories for the reason that all factories did not continually improve the effectiveness of the food safety program through the use of communication, management review, internal audit and evaluation of individual verification results. Concerning to the Updating food safety program not applicable scored resulted by all Factories was due to lack of evaluation and updating activities based on Input from communication, external as well as internal, Input from other information concerning the suitability, adequacy and effectiveness of the food safety management system and Output from the analysis of results of verification activities.

\section{Abstract gaps and weak points in the elements of Food Safety program in Sudanese sugar industries with refe- rence to FSMS of the ISO 22000, 2005}

Through auditing 29 dimensions of food safety programs with reference to FSMS of the ISO $22000[2,3]$. In six Sudanese sugar industries, the results can be summarized as follows: (1) All Sudanese sugar industries were not implemented any food safety programs to ensure food safety products. (2) The arithmetic mean of documentation that supports food safety programs has major deficiencies in five factories according to FSMS requirements of the ISO $22000(2,3)$. (3) The General Arithmetic means of Management responsibility has noncompliance in three factories according to FSMS requirements of the ISO $22000(4,5)$. (6) The General Arithmetic means of Resource Management in all Sudanese sugar industries has scored major deficiencies in requirement except one factory scored minor deficiency when compared with FSMS requirements of the ISO $22000[4,5]$. (5) The General Arithmetic means of Planning and realization of safe products has scored Non-compliance in three out of six factories while the General Arithmetic means for the rest factories has scored not applicable when compared with FSMS requirements of the ISO $22000[4,5]$. (6) The General Arithmetic means of Validation and verification and improvement of food safety programs scored not applicable in investigated Sudanese Sugar when compared with FSMS requirements of the ISO 22000 [4,5]. It can be concluded that the General Arithmetic means of all five categories of FSMS in all Sudanese sugar industries recorded not applicable final score with reference to FSMS of the ISO $22000[4,5]$. As it shown in Table 8.

The difficulties and challenges to implementing Food safety management systems ISO 22000 in Sudanese sugar industries

The General Arithmetic means of the difficulties and challenges to implementing Food safety management systems ISO $22000[4,5,17]$. In Sudanese sugar industries was higher than 4.5 for each factory this mean is corresponding the strongly agree with flowing the difficulties and constraints; Food safety management system implementation costs; Employees' qualification; Difficulties in use of the food safety management system tools and methodologies; Lack of top management motivation and involvement; Lack of top management commitment and involvement; Lack of government support; Not required by the Government or Public Agencies; Lack of knowledge in safety systems (HACCP and ISO22000) and Unaware of the advantages of ISO 22000 certification that are limited implementing this international standard Table 9.

\section{Conclusion}

Sudanese sugar industries were not implementing any food safety management system (FSMS). Requirement of management responsibility scored non-compliance in three factories according to FSMS requirements of the ISO 22000: 2005. Requirement of planning and realization of safe products, three out of six factories scored non-compliance while the rest factories scored not applicable when compared with FSMS requirements of the ISO 22000: 2005. Concerning the requirement of validation, verification and improvement of food safety programs, Sudanese Sugar industries scored not applicable as compared with FSMS requirements of the ISO 22000: 2005. Interestingly, the Sudanese sugar companies take

Table 8: Abstract Gaps and Weak points in the elements of Food Safety program in Sudanese sugar industries with reference to FSMS of the ISO 22000,2005

\begin{tabular}{|c|c|c|c|c|c|c|c|}
\hline & & & & Indu & ries & & \\
\hline Categories of ISO 22000 & $\begin{array}{l}\text { Elements } \\
\text { Number }\end{array}$ & Kenana & White Nile & Assalaya & Sennar & Guneid & New Halfa \\
\hline Food safety management system & 2 & 3.00 & 3.50 & 3.25 & 3.25 & 2.75 & 2.75 \\
\hline Management responsibility & 8 & 1.88 & 1.88 & 1.75 & 1.75 & 1.75 & 1.88 \\
\hline Resource management & 4 & 3 & 3.5 & 3 & 3 & 2.75 & 2.75 \\
\hline Planning and realization of safe products & 10 & 2.23 & 2.23 & 1.54 & 1.38 & 1.38 & 2.0 \\
\hline $\begin{array}{l}\text { Validation, verification and improvement } \\
\text { of the FSMS }\end{array}$ & 5 & 1 & 1 & 1 & 1 & 1 & 1 \\
\hline General Arithmetic means & 29 & 2.22 & 2.37 & 2.13 & 2.10 & 1.83 & 1.83 \\
\hline Verbal & Elements & Not applicable & Not applicable & Not applicable & Not applicable & Not applicable & Not applicable \\
\hline
\end{tabular}

Citation: AM Babeker, MA Ebrahiem, AR Ahmed, GA Mustafa (2022) Evaluation of the Existing Food Safety Management System (FSMS) Implemented in Sudanese Sugar industries. J Agric Sc Food Technol 8(1): 021-027. DOI: https://dx.doi.org/10.17352/2455-815X.000140 
Table 9: The difficulties and challenges to implementing Food safety management systems ISO 22000 in Sudanese sugar industries and their Prerequisites program.

\begin{tabular}{|c|c|c|c|}
\hline difficulties and Constraints & means & $\begin{array}{l}\text { Standard } \\
\text { deviation }\end{array}$ & Verbal \\
\hline $\begin{array}{l}\text { Food safety management system } \\
\text { implementation costs }\end{array}$ & 5.00 & 0.00 & $\begin{array}{l}\text { Strongly } \\
\text { agree }\end{array}$ \\
\hline Employees' qualification & 4.82 & 1.86 & $\begin{array}{l}\text { Strongly } \\
\text { agree }\end{array}$ \\
\hline $\begin{array}{l}\text { Training of employees involved in food } \\
\text { safety }\end{array}$ & 4.03 & 1.54 & agree \\
\hline $\begin{array}{l}\text { Reduction of the employees' time to make } \\
\text { other tasks }\end{array}$ & 4.00 & 1.48 & agree \\
\hline $\begin{array}{l}\text { Lack of top management' motivation and } \\
\text { involvement }\end{array}$ & 5.00 & 0.00 & $\begin{array}{l}\text { Strongly } \\
\text { agree }\end{array}$ \\
\hline $\begin{array}{l}\text { Lack of top management commitment } \\
\text { and involvement }\end{array}$ & 5.00 & 0.00 & $\begin{array}{l}\text { Strongly } \\
\text { agree }\end{array}$ \\
\hline Lack of prerequisite & 3.86 & 1.73 & agree \\
\hline Lack of government support & 5.00 & 0.00 & \\
\hline $\begin{array}{l}\text { Not required by the Government or Public } \\
\text { Agencies }\end{array}$ & 5.00 & 0.00 & $\begin{array}{l}\text { Strongly } \\
\text { agree }\end{array}$ \\
\hline $\begin{array}{l}\text { Lack of knowledge on safety } \\
\text { systems (HACCP \& ISO22000) }\end{array}$ & 5.00 & 0.00 & $\begin{array}{l}\text { Strongly } \\
\text { agree }\end{array}$ \\
\hline $\begin{array}{c}\text { Unaware of the advantages of ISO } 22000 \\
\text { certification }\end{array}$ & 5.00 & 0.00 & $\begin{array}{l}\text { Strongly } \\
\text { agree }\end{array}$ \\
\hline
\end{tabular}

Note: Score 1 = Strongly disagree at all; 5 = Strongly agree

all food quality characteristics from cane production to sugar production carefully, but unfortunately don't care about any food safety systems. Sudanese sugar industries adopted quality management system at all levels of production line but did not adopt any food safety systems. The Barriers of implementing food safety systems in Sudanese sugar companies were lack of knowledge, high cost of implementing Food safety management system, Employees qualification, Lack of top management motivation and involvement, Lack of top management commitment and involvement, Lack of government support, Not required by the Government or Public Agencies, Lack of knowledge in safety systems (HACCP and ISO22000) and Unaware of the advantages of ISO 22000 certification that are limiting implementation of international standards.

\section{Acknowledgments}

Deep appreciation expressed to Prof. Abdel Halim Rahama Ahmed and Dr. Ghada Ibrahim Mustafa, for their support and encouragement. Also, deep appreciation was expressed to Prof. Moyad Balal for his helpin completing this study. The author would like to express gratitude to production management and employees of sugar industries for providing appropriate information to conduct this study.

\section{References}

1. FAO WHO (2021) A guide to World Food Safety Day. World Food Safety Day 1-7. Link: https://bit.ly/3GjD6wE

2. Escanciano C, Santos-Vijande ML (2014) Reasons and constraints to implementing ISO 22000 food safety management system: Evidence from Spain. Food Control 40: 50-57. Link: https://bit.ly/33qAuhG

3. Fahmi A Rub, Penelope S, Abu Fahmi, Fahmi Abu (2020) Food Safety Management Systems. Book· Gavin Publications Link: https://bit.ly/3qjl0En

4. ISO International Standard Organization (2005) Food safety management systems: Requirements for any organization in the food chain. International Standard ISO, Switzerland. Link: https://bit.ly/3fwtTFz

5. ISO International Standard Organization (2005) Food safety management systems: Requirements for any organization in the food chain. International Standard ISO Switzerland. Link: https://bit.ly/3K3tWX7

6. Smith D, Jackson-Smith T, Politowski R (2007) ISO 22000 Food safety: guidance and workbook for the manufacturing industry. London: BSI. Link: https://bit.ly/3ffG1dW

7. Soares NF, Vicente AA, Martins CMA (2016) Food safety in the seafood. Environ Protect Ecol 8: 841-849. Link: https://bit.ly/3HYukEw

8. Sheps I (2007) ISO 22000: The new international standard on food safety - A comparison to HACCP (Danish Standard DS 3027, 2. edition) J Environ Protect Ecol 8: 940-949.

9. Arvanitoyannis IS, Varzakas TH (2009) Application of ISO 22000 and Comparison with HACCP on Industrial Processing of Common Octopus (Octopus Vulgaris)- Part I. Int J Food Sci Technol 44: 58-78. Link: https://bit.ly/3njRBsD

10. Al Yousuf M, Taylor E, Taylor J (2015) Developing a government strategy to meet international standards of food safety across the hospitality industry. Worldwide Hospitality and Tourism Themes 7: 4-16. Link: https://bit.ly/3HWnFuv

11. Smith R (1994) Food hygiene training: the chance to create a coherent training policy. Br Food J 96: 41-45. Link: https://bit.ly/3I2MMMx

12. Escanciano C, Santos-Vijande ML (2014) Implementation of ISO-22000 in Spain: obstacles and key benefits. Br Food J 116: 1581-1599. Link: https://bit.ly/3FkRkft

13. Walker $\mathrm{E}$, Jones $\mathrm{N}$ (2002) An assessment of the value of documenting food safety in small and less developed catering businesses. Food Control 13 : 307-314. Link: https://bit.ly/3rbZS3a

14. Afoakwa EO, Mensah-Brown H, Crentsil, GK, Frimpong K, Asante F (2013) Application of ISO 22000 in comparison with HACCP on industrial processing of milk chocolate. Int Food Res J 20: 1771-1781. Link: https://bit.ly/3Go71Uc

15. Sorrel Brown (2010) Likert Scale Examples for Surveys ANR Program Evaluation lowa State University Extension Link: https://bit.ly/3I1pxIX

16. Soman R, Raman M (2016) HACCP system - hazard analysis and assessment based on ISO 22000:2005 methodologies. Food Control 69: 191-195. Link: https://bit.ly/34xXsUG

17. Sikora T, Nowicki P (2007) Food Safety Assurance According to Codex Alimentarius and ISO 22000 Standard. Polish J Food Nutr Sci 57: 489-493. Link: https://bit.ly/3ndGFgj

Discover a bigger Impact and Visibility of your article publication with

Peertechz Publications

Highlights

* Signatory publisher of ORCID

* Signatory Publisher of DORA (San Francisco Declaration on Research Assessment)

* Articles archived in worlds' renowned service providers such as Portico, CNKI, AGRIS, TDNet, Base (Bielefeld University Library), CrossRef, Scilit, J-Gate etc.

* Journals indexed in ICMJE, SHERPA/ROMEO, Google Scholar etc.

* OAI-PMH (Open Archives Initiative Protocol for Metadata Harvesting)

* Dedicated Editorial Board for every journal

* Accurate and rapid peer-review process

* Increased citations of published articles through promotions

* Reduced timeline for article publication

Submit your articles and experience a new surge in publication services (https://www.peertechz.com/submission).

Citation: AM Babeker, MA Ebrahiem, AR Ahmed, GA Mustafa (2022) Evaluation of the Existing Food Safety Management System (FSMS) Implemented in Sudanese Sugar industries. J Agric Sc Food Technol 8(1): 021-027. DOI: https://dx.doi.org/10.17352/2455-815X.000140 